\title{
The effect of different compost rates on the yield of ryegrass (Lolium perenne L.)
}

\author{
Anita Szabó - Imre Vágó \\ University of Debrecen, Centre for Agricultural and Applied Economic Sciences \\ Faculty of Agricultural and Food Sciences and Environmental Management \\ Institute of Agricultural Chemistry and Soil Science, H-4032, Debrecen, Hungary \\ szaboanita@agr.unideb.hu
}

Keywords: recycling, compost dose, plant $N$-content

SUMMARY

Protection of natural resources and sustainable natural resources management are essential for the long-term survival of humanity. This makes necessary nowadays the development of environmentally conscious living and spread of that in the future. The amount of organic waste materials, produced during human activities, could be decreased by composting instead of dispose them in landfills. Applying appropriate treatment technology and additives, the compost could be used as fertilizer for horticultural crops and it could increase the easily available nutrient content of soils. Compost utilization prevents nutrient deficiencies and by using the optimal rate, we could reach significant yield increases.

\section{INTRODUCTION}

Many authors found that composts made by biological waste materials have a favorable effect on soil fertility (Lee et al., 2003; Arancon et al., 2004; Füleky - Benedek, 2010) and increase the nutrient uptake of plants and their yields. In contrast, according to Kádár et al. (2009), compost fertilization did not increase yield. The differences come from the different and diverse composition of composts, which are also influenced by seasonality.

In spring and autumn, the primary materials of compost could be twigs originated from the pruning of trees and bushes or an agricultural straw/chaff mixture. In summer, the amount of agro-industrial by-products could be dominant. With the recycling of these seasonal organic wastes, the amount of wastes disposed in landfills (Simándi, 2008) could be decreased and compost with a diverse composition could be produced.

After amassing the primary materials, we complete the treatment with additives (bacterial cultures). It is also important to measure the temperature during the process of composting (Alexa-Dér, 1998). As an effect of microorganisms, toxic substances are neutralized, organic matters are mineralized and the produced carbon dioxide is emitted to the air (Dienes, 2002). The quality of the end product is related to the conditions of mineralization and the composition of the primary materials (Kocsis, 2005).

Production of high quality composts and their application with horticultural crops solves not only the problem of waste disposition, but has a favorable effect on soil characteristics and increases soil fertility (Elfoughi et al., 2010). Thus, it can increase the yield, as well (Gigliotti et al., 1966; Kádár-Morvai, 2007; Keserü, 2007).

\section{MATERIALS AND METHODS}

We received the studied compost from one of the partners of University of Debrecen in the summer of 2009. The pot-experiment under controlled conditions was set up in the greenhouse of the Institute of Agricultural Chemistry and Soil Science. Compost was sieved $(<2 \mathrm{~mm})$, because degradation of the large particles in the pots is slow. Compost was mixed with acidic sandy soil in four proportions $(5 \%, 10 \%, 25 \%$ and $50 \%)$, so with the control there were five treatments in four replications (Table 1). After the volumetric mixture, we set up the pots in a randomized way.

The compost-soil ratio of treatments

\begin{tabular}{|c|c|c|}
\hline Treatments & Compost ratio (\%) & Sandy soil ratio (\%) \\
\hline 1. & 0 & 100 \\
\hline 2. & 5 & 95 \\
\hline 3. & 10 & 90 \\
\hline 4. & 25 & 75 \\
\hline 5. & 50 & 50 \\
\hline
\end{tabular}


After one week maturation of wet compost-soil mixture, on $7^{\text {th }}$ of September, we sowed perennial ryegrass (Lolium perenne L.). This indicator plant grows fast, tolerates the greenhouse conditions well and it indicates the effect of treatments well. There was not any effect of precipitation in the greenhouse. After the shooting of ryegrass $\left(21^{\text {st }}\right.$ of September), the water supply of the $2.5 \mathrm{~kg}$ pots was carried out at 60 per cent of field water capacity of soil. Previous research of the Department of Agricultural Chemistry confirmed that irrigation at 60 per cent of field water capacity is optimal in sandy soils (Loch et al., 1992).

After four weeks, we harvested ryegrass $\left(15^{\text {th }}\right.$ of October). After air-drying and $40{ }^{\circ} \mathrm{C}$ drying to constant mass of plant matter, we measured the dry matter production. We investigated the $0.01 \mathrm{~mol} \mathrm{dm}^{-3} \mathrm{CaCl}_{2}$ extractable $\mathrm{NO}_{3}-\mathrm{N}, \mathrm{NH}_{4}-\mathrm{N}, \mathrm{N}_{\text {org }}$ and $\mathrm{N}_{\text {total }}$ contents and $\mathrm{CaCl}_{2}$-pH of soils.

\section{Chemical analysis:}

Air dried and sieved $(<2 \mathrm{~mm})$ soil samples were shaken for 2 hours with $0.01 \mathrm{M} \mathrm{CaCl}_{2}$ extractant $(1: 10$ soil: solution ratio) according to Houba et al. (1990). Suspensions were centrifuged in a bench centrifuge at $2500 \mathrm{rpm}$ for 10 minutes and the supernatant were analyzed with an autoanalyzer (Continuous Flow Analyzer, Scalar SANPLUSSYSTEM), at the laboratory of the Institute of Agricultural Chemistry and Soil Science. $N_{\text {total }}$ fraction contains inorganic $\left(\mathrm{NO}_{3}-\mathrm{N}+\mathrm{NH}_{4}-\mathrm{N}\right)$ and easily soluble, oxidizable organic nitrogen $\left(N_{\text {org }}^{\text {total }}\right)$. $N_{\text {org }}$ was calculated by the difference of $N_{\text {total }}$ and inorganic nitrogen forms $\left(\mathrm{NO}_{3}-\mathrm{N}+\mathrm{NH}-\mathrm{N}\right)$. We measured the $\mathrm{pH}$ of the soils after $0.01 \mathrm{M} \mathrm{CaCl}_{2}$ extraction.

\section{Statistical analyses:}

We used variance analyses for the processing of the data. All statistical analyses were performed with Microsoft Excel Macro (Tolner et al., 2008; Vágó et al., 2008) according to Sváb (1981). With this program, we determined the significance level of the treatment effect and significant differences at $\mathrm{P} \leq 0.05$.

\section{RESULTS AND DISCUSSION}

The average values of the fresh weight and dry weight of ryegrass in each treatment are represented in Figure 1 and 2 . The fresh and dry weights depend on the treatments significantly $(\mathrm{P} \leq 0.01)$.

Figure 1: Fresh weight production of ryegrass in each treatment $\left(\mathrm{g} \mathrm{pot}^{-1}\right)$

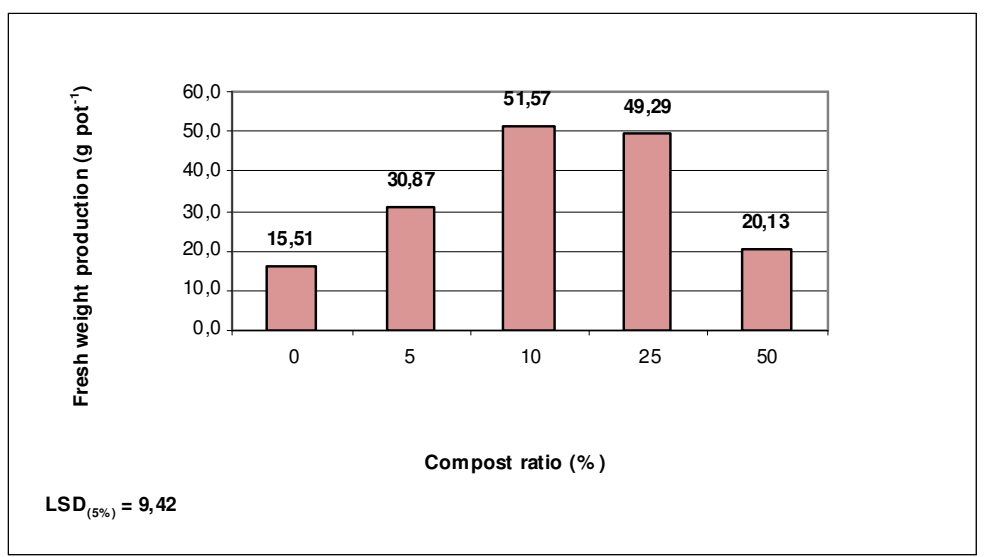

Figure 2: Dry matter production of ryegrass in each treatment $\left(\mathrm{g} \mathrm{pot}^{-1}\right)$

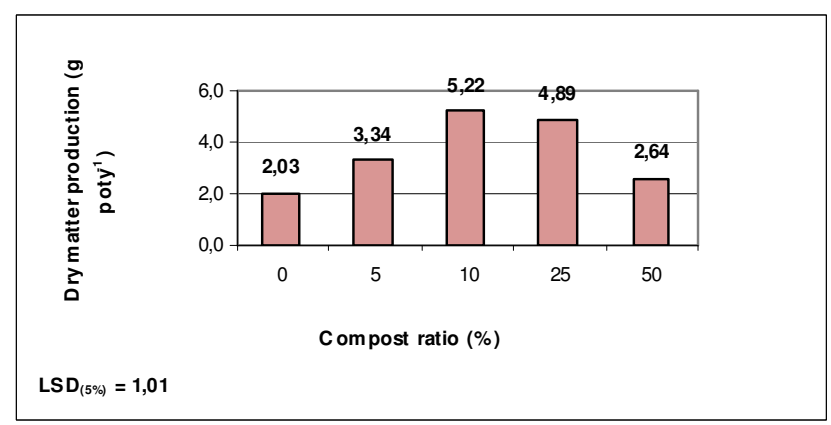


According to the yield data, the $10 \%$ compost rate had the highest positive effect. The effect of $25 \%$ rate is moderate and not significant, but the yield of 50\% rate compost treatment was significantly lower than that of 10 and $25 \%$ treatments. We can explain this with the high organic matter content, and unfavorable nutrient uptake conditions. The results confirmed that the high rate compost treatment has unfavorable effects as well. The optimal compost dose was between 10 and $50 \%$ rate.

The $0.01 \mathrm{M} \mathrm{CaCl}_{2}$ extractable $\mathrm{N}$ fractions of soils after harvest are shown in Figure 3. By the increasing of compost rate each $\mathrm{N}$ fraction increased consequently. The significance level is $\mathrm{P} \leq 0.01$. The $\mathrm{NO}_{3}-\mathrm{N}$ fraction was dominant among $\mathrm{N}$ forms in the case of this compost. The $10 \%$ compost rate has also significant increasing effect on each $\mathrm{N}$ form. The low yields in 50\% compost treatment could be related to the high nitrate and ammonium concentrations, the reason of this is the supraoptimal concentration of the $\mathrm{N}$ forms.

Figure 3: $\mathbf{N}$ fractions of soils after harvest $\left(\mathrm{mg} \mathrm{kg}^{-1}\right)$

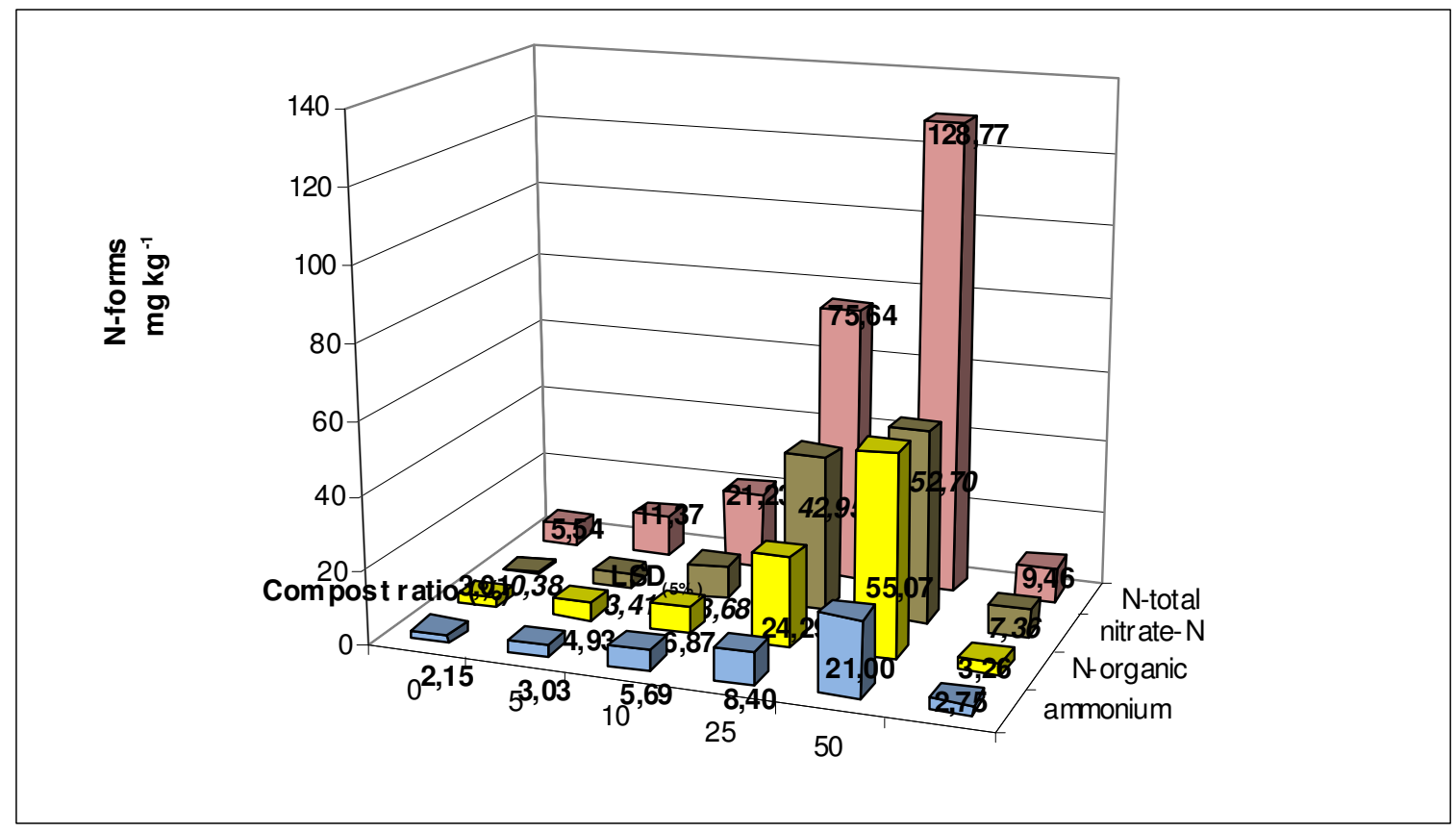

Figure 4: The $\mathbf{C a C l}_{2}-\mathbf{p H}$ of soils after harvest

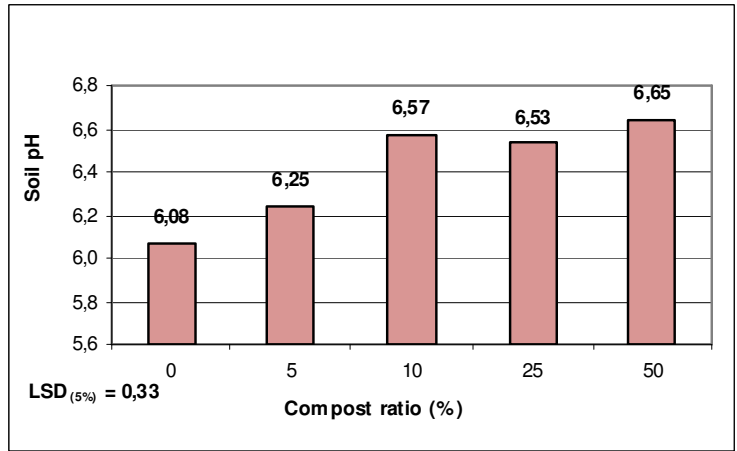

The $\mathrm{CaCl}_{2}-\mathrm{pH}$ of soils after harvest is represented in Figure 4. The $\mathrm{pH}$ of the applied compost was 7.3. It can be stated that the $\mathrm{pH}$ of acidic sandy soil increased into the neutral range as an effect of compost, but the organic acid excretion of root may also influence it. The optimal $\mathrm{pH}$ value is slightly acidic in aspect of nutrient uptake, so the $\mathrm{pH}$ of the soil-compost mixture was favorable for the plant.

The $\mathrm{pH}$ in the $25 \%$ compost treatment was lower than that in the $10 \%$ treatment, but the difference is not significant. The measurements error is lowered by the four replications. The $5 \%$ compost rate has also significant increasing effect on $\mathrm{pH}$ so the $\mathrm{pH}$ didn't cause problems in nutrient uptake and yield decrease. 


\section{CONCLUSIONS}

It can be concluded that the $10 \%$ compost rate had the most favorable effect on yield. The optimal rate probably varies between 10 and $25 \%$. The $50 \%$ rate seemed to inhibit the growth of ryegrass. This effect is not related to the $\mathrm{pH}$ of compost-soil mixtures, because the $\mathrm{pH}$ was optimal in aspect of nutrient uptake in each treatment. We can explain the yield decrease with the high nitrate and ammonium contents of soil which may cause not appropriate nutrient proportions in soil solution, but the explanation of this effect needs further investigations.

\section{REFERENCES}

Alexa L.-Dér S. (1998): A komposztálás elméleti és gyakorlati alapjai. FVM Bio-Szaktanácsadó Bt., Bp 136.

Arancon, N. Q.-Edwards, C.A.-Bierman, P.-Metzger, J.D.-Lee, S.-Welch, C. (2004): Effects of vermicomposts on growth and marketable fruits of field-grown tomatoes, peppers and strawberries. Pedobiologia. 47. 731-735.

Dienes É. (2002): Különböző összetételű komposztok fizikai, kémiai, mikrobiológiai jellemzése. Agrártudományi Közlemények, Debrecen. II. 15-18.

Elfoughi, A.-Benedek, Sz.-Bayoumi, H.H.E.A.F.-Füleky, Gy. (2010): Komposzttrágyázás hatásának vizsgálata a talaj tápelem-szolgáltató képességére. Agrokémia és Talajtan 59 (2010) 2

Füleky, Gy.-Benedek, Sz. (2010): Composting as recycling of biowaste. A review. In: Sustainable Agriculture Reviews (Ed.: Lichtfouse, E.) Vol. 3. Sociology, Organic Farming, Climate Change and Soil Science. 319-346. Springer. The Netherlands.

Gigliotti, G.-Businelli, D.-Giusquiani, P.L. (1966): Trace metal uptake and distribution in corn plants grown on a 6-year urban waste compost amended soil. Agric. Ecosyst. and Environm. 58. 199-206. p.

Houba, V.J.G.-Novozamsky, L.-Lexmond, T.M.-Van der Lee, J.J. (1990): Applicability of 0,01 M CaCl2 as a single extraction solution for the assessment of the nutrient status of soils and other diagnostic purposes. Commun. Soil Sci. Plant Anal. 21. 2281-2290.

Kádár I.-Morvai B. (2007): Ipari-kommunális szennyvíziszap-terhelés hatásának vizsgálata tenyészedény-kísérletben. Agrokémia és Talajtan. 56 (2007) 2

Kádár I.-Morvai B. (2009): Városi szennyvíziszap-terhelés hatásának vizsgálata tenyészedény-kísérletben. IV. Agrokémia és Talajtan. 58. 91-104.

Keserü Zs. (2007): A szennyvíziszap-komposzt erdészeti hasznosíthatóságának kérdései. Erdészeti, Környezettudományi, Természetvédelmi és Vadgazdálkodási Tudományos Konferencia (EKTV-TK) konferencia 2007. december 11. Sopron.

Kocsis I. (2005): Komposztálás. Szaktudás Kiadó Ház Rt., Budapest. 41-44, 138.

Lee J.J.-Park, R.P-Kim, Y.W.-Shim, J.H.-Chae, D.H.-Rim, Y.S.-Sohn, B.K.-Kim, T.H.-Kim, K.Y. (2003): Effect of food waste compost on microbial population, soil enzyme activity and lettuce growth. Bioresource Technol. 93. 21-28.

Loch J.-Kiss Sz.-Vágó I. (1992): A kálium-, kalcium-, magnézium- és vízellátás hatása az őszi búza szemtermésére és magnéziumfelvételére. 4. Magyar Magnézium Szimpózium, Balatonszéplak. In: Magnesium Research 5. Abstr. 238.

Simándi P. (2008): Különböző szerves hulladékok és kezelésük után keletkezett termékek kémiai vizsgálata. Értekezés, Debrecen. 8.

Sváb J. (1981): Biometriai módszerek a kutatásban. Mezőgazdasági Kiadó, Budapest.

Tolner L.-Vágó I.-Czinkota I.-Rékási M.-Kovács Z. (2008): Field testing of a new, more efficient liming method. Cereal Research Communications. 36. 543 - 546.

Vágó I.-Tolner L.-Eichler-Löbermann B.-Czinkota I.-Kovács B. (2008): Long-term effects of liming on the dry matter production and chemical composition of perennial ryegrass (Lolium perenne L.). Cereal Research Communications. 36. 103 - 106. 